\title{
Relationship between stylohyoid ligament calcification and systemic osteoporosis by CBCT and panoramic radiography
}

\author{
- Emiko Saito Arita Discipline of Oral Radiology, Department of Stomatology, School of Dentistry, University of São Paulo, São \\ Paulo, SP, Brazil • Karina Cecília Panelli Santos Discipline of Oral Radiology, Department of Stomatology, School of Dentistry, \\ University of São Paulo, São Paulo, SP, Brazil • Junichi Asaumi Discipline of Oral and Maxillofacial Radiology, Okayama University \\ Graduate School of Medicine, Dentistry, Pharmaceutical Science, Okayama, Japan • Jefferson Xavier Oliveira Discipline of Oral \\ Radiology, Department of Stomatology, School of Dentistry, University of São Paulo, São Paulo, SP, Brazil
}

ABSTRACT | The purpose of this study was to use panoramic radiography and cone beam computed tomography images to investigate (1) the accuracy of these methods concerning osteopenia and osteoporosis diagnosis, and (2) the correlation between presence of stylohyoid ligament calcification and osteopenia and osteoporosis. A hundred seventy-one images from a digital archive were used in this study. All panoramic radiography and cone beam computed tomography images were obtained using the Veraviewepocs 3D system and observed with the i-VIEW-3DX software. For osteopenia and osteoporosis diagnosis, the mandibular cortex was assessed. Presence of stylohyoid ligament calcification was also assessed and mineralization in all parts of the stylohyoid complex was considered. All recorded data were referred to statistical analysis and the significance level was set at $5 \%$. There is an agreement between the imaging modalities for osteopenia and osteoporosis diagnoses, since the rate of disagreement is $21.6 \%$. The results confirmed the osteoporosis diagnosis in older women and the correlation between osteopenia and osteoporosis diagnoses and the presence of stylohyoid ligament calcification $(\mathrm{p}=0.06)$. The present study suggests that (1) panoramic radiography and computed tomography images are accurate enough for osteopenia and osteoporosis diagnoses with low disagreement rate between methods, and (2) there is a significant correlation between presence of stylohyoid ligament calcification and osteopenia and osteoporosis diagnoses in older women.

DESCRIPTORS | Age-related Osteoporosis; Diagnostic X-Ray; Pathologic Calcification.

RESUMO | Relação entre calcificação do ligamento estiloide e osteoporose sistêmica a partir de imagens de TCFC e radiografias panorâmicas - O objetivo deste estudo foi investigar, a partir de imagens de tomografia computadorizada por feixe cônico e radiografias panorâmicas, (1) a acurácia dos métodos no diagnóstico de osteoporose e osteopenia e (2) a correlação entre a calcificação do ligamento estiloide e o diagnóstico de osteopenia e osteoporose. Foi utilizado um arquivo digital composto por 171 imagens. Tanto as imagens tomográficas quanto as radiografias panorâmicas foram obtidas com o aparelho Veraviewepocs 3D e observadas com auxílio do programa i-VIEW-3DX. Para o diagnóstico de osteopenia e osteoporose, a cortical mandibular foi avaliada. A presença de calcificação no ligamento estiloide foi verificada, considerando-se mineralização em todas as partes do complexo estiloide. Foi realizada a análise estatística dos dados tabulados, e o nível de significância foi estabelecido em $5 \%$. O resultado apontou correlação entre os métodos de imagem no diagnóstico de osteopenia e osteoporose. Confirmou-se também a maior frequência de osteoporose em mulheres com idade avançada e a correlação entre os diagnósticos de osteopenia e osteoporose e a presença de calcificação no complexo estiloide $(p=0,06)$. O presente estudo sugere que (1) tanto a radiografia panorâmica quanto as imagens de tomografia computadorizada por feixe cônico podem ser usadas no diagnóstico de osteopenia e osteoporose e (2) há correlação significativa entre a calcificação do ligamento estiloide e o diagnóstico de osteopenia e osteoporose em mulheres com idade avançada.

DESCRITORES | Osteoporose; Raios X Diagnósticos; Calcificação Patológica.

CORRESPONDING AUTHOR | • Karina Cecília Panelli Santos Discipline of Oral Radiology, Department of Stomatology, School of Dentistry, University of São Paulo - Av. Prof. Lineu Prestes, 2227 São Paulo, SP, Brazil • 05508-900 E-mail: kapanelli@usp.br

- Received Dec 10, 2014 • Accepted Feb 12, 2015

- Dol http://dx.doi.org/10.11606/issn.2357-8041.clrd.2016.98347 


\section{INTRODUCTION}

Calcium is an essential nutrient for the human body and has received substantial attention due to its role in osteoporosis and several other chronic diseases. It is the most abundant mineral in the human body and $99 \%$ of its stores are found in the skeleton. The remaining stores are in soft tissues (0.9\%) and the bloodstream and extracellular fluid (0.1\%). ${ }^{1}$ Calcium requirements remain stable until menopause, when the bone resorption rate increases in parallel with the decrease in ovarian estrogen production. Adequate calcium intake (combined with adequate vitamin D status) has been shown to reduce bone loss in postmenopausal women, being the key component for patients with osteoporosis. In addition, women at menopause require increased calcium concentration due to their absorption deficiency. ${ }^{1-3}$

Osteoporosis is a systemic condition characterized by low bone mass, leading to bone fragility. ${ }^{1,2}$ Several factors are related to osteoporotic fractures in postmenopausal women, such as history of fractures in adulthood, smoking, estrogen deficiency at an early age, physical inactivity, little exposure to sunlight, and alcohol abuse, in addition to low calcium intake. ${ }^{2,3}$ Although densitometric techniques are well established for osteoporosis diagnosis, some studies have shown that dentists can assess mandibular bone quality using panoramic radiography (PAN). By analyzing the sparse trabeculation of mandibular cortex, they subjectively determine the risk of osteoporosis. ${ }^{4,5}$

On the other hand, calcifications of soft tissues in the maxillofacial area are uncommon and usually correspond to radiographic findings in routine imaging examination. Anatomical location, distribution and number, size, and shape of calcifications are the most important diagnostic criteria. ${ }^{6}$ Stylohyoid ligament calcification (SLC) is generally diagnosed as a dystrophic calcification, which ranges from barely perceptible to large radiopaque particles. ${ }^{78}$ Its etiology is still unclear, and some theories include degeneration of the ligament, with deposition of calcium in fibrous tissue or malformation due to direct ossification of the cartilaginous cells remaining in the ligament. ${ }^{8}$ The emergence of cone beam computed tomography (CBCT) has expanded the field of oral and maxillofacial radiology. CBCT imaging provides three-dimensional volumetric data construction with high dimensional accuracy of dental and associated maxillofacial structures. ${ }^{9,10}$ Besides that, some studies have already shown that $\mathrm{CBCT}$ images can be used to assess osteoporotic women and also to evaluate size and morphology of the stylohyoid complex. ${ }^{11,12}$

The purpose of this study was to use PAN and CBCT images to investigate (1) the accuracy of these methods concerning osteopenia and osteoporosis diagnosis, and (2) the correlation between presence of SLC and osteopenia and osteoporosis.

\section{MATERIAL AND METHODS}

A hundred seventy-one images from a digital archive of patients from the Radiology Service of the Okayama University Graduate School of Medicine, Dentistry and Pharmaceutical Sciences (Japan) were used in this study. Patients with metabolic bone diseases and pathologies or fractures in the region of the stylohyoid complex were excluded from this study. ${ }^{11,12}$

All CBCT and PAN images were obtained using the Veraviewepocs $3 \mathrm{D}$ system (J. Morita Corporation, Kyoto, Japan; 6o-80 Kv, 1-10 mA). The field of view (FOV) protocol was established as 80 $\times 80 \mathrm{~mm}$ (scan time: $9.4 \mathrm{~s}$ ) for CBCT and $40 \times 80$ mm (scan time: $15 \mathrm{~s}$ ) for PAN. All images were observed using the i-VIEW-3DX software (J. Morita Corporation, Kyoto, Japan). One experienced specialist with a $\mathrm{PhD}$ in Oral and Maxillofacial Radiology performed image analysis.

For osteopenia and osteoporosis diagnoses, the mandibular cortex was classified as follows: 
(C1), if the endosteal margin of the cortex was sharp on both sides; (C2), if the endosteal margin showed semilunar defects (lacunar resorption) and/or presented cortical residues on one or both sides; and ( $\left.\mathrm{C}_{3}\right)$, if the endosteal margin was clearly porous. ${ }^{13}$ This classification was used for evaluation of the digital PAN and CBCT images. In the CBCT images, after reconstruction of the acquired data, a panoramic view of the jaw was obtained with $20 \mathrm{~mm}$ thickness, and this image was considered for mandibular cortex evaluation.

Presence of SLC was also assessed in PAN and CBCT images, and mineralization in all parts of the stylohyoid complex was considered SLC. Length of the styloid process was measured from the base to the tip of each appendix by using software tools. Processes measuring more than 30 $\mathrm{mm}$ were considered elongated. ${ }^{14}$ For CBCT data, all measurements were performed at the right and left oblique sagittal planes from $3 \mathrm{D}$ multiplanar reconstruction..$^{12}$ If there was a segmental SLC, the distance was measured including the non-calcified parts.

All recorded data were referred to statistical analysis by using the software R 3.0.2 (AlcatelLucent, Murray Hill, New Jersey, USA). The significance level was set at $5 \%$.

Comparison between PAN and CBCT methods for osteopenia and osteoporosis diagnoses is presented in cross-tabs with relative and absolute frequencies. McNemar's test was utilized to verify which of them was more sensitive. ${ }^{15}$ Continuous variables were described by means of statistical position (minimum, maximum, and average) and scale (standard deviation).

By using Fisher's exact test, osteopenia and osteoporosis diagnoses were associated with SLC presence and patient gender. For correlation between osteopenia and osteoporosis diagnoses and patient age, analysis of variance (ANOVA) with a linear model was used. ${ }^{16}$

\section{RESULTS}

This study included 171 patients, 55 males (32.2\%) and 116 females (67.8\%) with a mean age of 59.6 years. Table 1 shows the agreement between the imaging modalities. The rate of disagreement was $21.6 \%$. Neither PAN nor CBCT showed conflicts for normal and osteoporosis diagnoses.

Tables 2, 3, and 4 show the correlation between final diagnosis, age, and gender. Statistical description of patients' age is shown in Table 2. Table 3 shows the estimation of the coefficient linear model for age according to each diagnosis possibility. The mean age for normal patients was estimated to be 49.86 years, and this age is increased in 7.89 and 14.76 years for patients with diagnoses of osteopenia and osteoporosis, respectively. The p value (< o.oo1) from the ANOVA test confirmed the osteoporosis diagnosis in older adults.

Table 1 | Correlation between imaging modalities for osteopenia and osteoporosis diagnosis

\begin{tabular}{|c|c|c|c|c|c|c|c|c|}
\hline \multirow{3}{*}{$\mathrm{PAN}$ * } & \multicolumn{8}{|c|}{ СBCT** } \\
\hline & \multicolumn{2}{|c|}{ Normal } & \multicolumn{2}{|c|}{ Osteopenia } & \multicolumn{2}{|c|}{ Osteoporosis } & \multicolumn{2}{|c|}{ Total } \\
\hline & $\mathrm{N}$ & $\%$ & $\mathrm{~N}$ & $\%$ & $\mathrm{~N}$ & $\%$ & $\mathrm{~N}$ & $\%$ \\
\hline Normal & 63 & 36.8 & 12 & 7 & 0 & 0 & 75 & 43.8 \\
\hline Osteopenia & 8 & 4.7 & 36 & 21.1 & 12 & 7 & 56 & 32.8 \\
\hline Osteoporosis & 0 & 0 & 5 & 2.9 & 35 & 20.5 & 40 & 23.4 \\
\hline Total & 71 & 41.5 & 53 & 31 & 47 & 27.5 & 171 & 100 \\
\hline \multicolumn{8}{|c|}{ Rate of disagreement: } & 21.6 \\
\hline
\end{tabular}

* Panoramic Radiography, ** Cone Bean Computed Tomography 
Table 4 shows that presence of osteopenia and osteoporosis is more frequent in female patients, since the $\mathrm{p}$ value (Fisher's exact test) is 0.002 .

Considering that osteopenia and osteoporosis diagnoses were more frequent in females (Table 4), the relationship between presence of SLC and the aforementioned diseases was evaluated only in the female group (Table 5). The results, with a $\mathrm{p}$ value (Fisher's exact test) of 0.06, confirm that these diagnoses are associated with presence of SLC.

Table 2 | Statistical description of patients' age according to osteopenia and osteoporosis diagnosis

\begin{tabular}{|l|c|c|c|c|c|c|c|}
\hline Final diagnosis CBCT and PAN* & N & Minimum & Maximum & Mean & $\begin{array}{c}\text { Standard } \\
\text { deviation }\end{array}$ & \multicolumn{2}{c|}{ Cl for the mean $(95 \%) * *$} \\
Inf
\end{tabular}

* Final diagnosis including CBCT and PAN evaluation

**Confidence intervals for the mean values

Table 3 | Coefficient linear model for age according to osteopenia and osteoporosis diagnosis

\begin{tabular}{|l|c|c|c|c|}
\hline Coefficient & Estimate & Standard error & $t$ value & $p$ value \\
\hline Intercept & 49.86 & 1.31 & 38.08 & $<0.001$ \\
\hline Osteopenia & 7.89 & 1.91 & 4.14 & $<0.001$ \\
\hline Osteoporosis & 14.76 & 1.95 & 7.58 & $<0.001$ \\
\hline
\end{tabular}

Table 4 | Final diagnosis of osteopenia and osteoporosis according to patient gender

\begin{tabular}{|c|c|c|c|c|c|c|}
\hline \multirow{3}{*}{$\begin{array}{l}\text { Final Diagnosis } \\
\text { CBCT and PAN* }\end{array}$} & \multicolumn{6}{|c|}{ Gender } \\
\hline & \multicolumn{2}{|c|}{ Female } & \multicolumn{2}{|c|}{ Male } & \multicolumn{2}{|c|}{ Total } \\
\hline & $\mathrm{N}$ & $\%$ & $\mathrm{~N}$ & $\%$ & $\mathrm{~N}$ & $\%$ \\
\hline Normal & 34 & 29.3 & 29 & 52.8 & 63 & 36.9 \\
\hline Osteopenia & 38 & 32.8 & 18 & 32.7 & 56 & 32.7 \\
\hline Total & 116 & 100 & 55 & 100 & 171 & 100 \\
\hline \multicolumn{6}{|c|}{$p$ value from the Fisher's exact test } & 0.002 \\
\hline
\end{tabular}

* Final diagnosis including CBCT and PAN evaluation

Table 5 | Association of osteopenia and osteoporosis diagnosis and SLC in females

\begin{tabular}{|c|c|c|c|c|c|c|c|c|}
\hline \multirow{3}{*}{$\mathrm{SLC} * *$} & \multicolumn{8}{|c|}{ Final Diagnosis CBCT and PAN* } \\
\hline & \multicolumn{2}{|c|}{ normal } & \multicolumn{2}{|c|}{ osteopenia } & \multicolumn{2}{|c|}{ osteoporosis } & \multicolumn{2}{|c|}{ Total } \\
\hline & $\mathrm{N}$ & $\%$ & $\mathrm{~N}$ & $\%$ & $\mathrm{~N}$ & $\%$ & $\mathrm{~N}$ & $\%$ \\
\hline NO & 33 & 97.1 & 30 & 78.9 & 37 & 84.1 & 100 & 86.2 \\
\hline YES & 1 & 2.9 & 8 & 21.1 & 7 & 15.9 & 16 & 13.8 \\
\hline RTot & 34 & 100 & 38 & 100 & 44 & 100 & 116 & 100 \\
\hline \multicolumn{8}{|c|}{$p$ value from Fisher's exact test } & 0.06 \\
\hline
\end{tabular}

* Final diagnosis including CBCT and PAN evaluation

** Stylohyoid ligament calcification 


\section{DISCUSSION}

Calcium requirements for skeletal maintenance vary throughout women's life. During the teen years, calcium requirements are high because the skeleton grows rapidly. During their 20s, the body requires less calcium for bone health. It remains stable until menopause, when there is a lack of vitamin D and, according to the "Committee to Review Dietary Reference Intakes for Vitamin D and Calcium, Food and Nutrition Board", a decrease in intestinal absorption. ${ }^{1}$ In general, postmenopausal women should ingest $1,200 \mathrm{mg}$ calcium per day from different sources: foods, calcium-fortified foods, and supplements. ${ }^{17}$ The importance of adequate calcium intake for skeletal health is well established. ${ }^{1,17}$ Studies have demonstrated that postmenopausal women receiving calcium supplement for one year had decreased bone loss rate (0.014\%) compared with untreated women (1.0\%). ${ }^{18}$

Osteoporosis is a skeletal disorder that causes bone deterioration and affects the stomatognathic system with the same rate as that of the total skeleton. ${ }^{2,3}$ Disease and associated bone fractures, morbidity, mortality, and health care costs are significant health concerns. Therefore, effective preventive strategies, such as early diagnosis and treatment, must be established., ${ }^{2,19,20}$ Mandibular information regarding cortical thickness and morphology of the inferior cortex are useful, and radiographic examination of the mandible may be effective for the osteoporosis diagnosis. ${ }^{3-5,11}$ Panoramic mandibular index (PMI) has been used to assess mandibular bone quality, and it is well established in the literature worldwide. ${ }^{3-5,13,21,22}$ Although Klemetti et al. ${ }^{13}$ stated that the PMI should not be utilized to assess the patient's status regarding osteoporosis, Devlin and Horner ${ }^{21}$ and Arifin et al. ${ }^{22}$ reported that mandibular cortical width below the mental foramen, manually measured on dental panoramic radiographies, was significantly correlated with the $\mathrm{T}$ scores recorded for spine and femur. Koh and $\mathrm{Kim}^{11}$ emphasized the importance of CBCT in mandibular evaluation and showed different results for normal and osteoporotic groups. This study presents imaging data regarding jaw assessment on PAN and CBCT exams, which showed to be useful tools for mandibular cortex evaluation, with low disagreement rate (21.6\%), as shown in Table 1. In addition, misdiagnosis did not occur in the normal and osteoporotic groups (Table 1), in agreement with the results of Koh and $\mathrm{Kim}^{11}$.

Although men experience age-related bone loss, possibly resulting in osteoporosis, the condition is most commonly associated with women. Incidence of fractures in men increases 5-10 years later than in women. ${ }^{1-3,17,19,20}$ These statements mentioned above are presented in Tables 2, 3, and 4. Tables 2 and 3 show the correlation between patient age and disease severity, thus confirming that osteoporosis incidence increases with age. Table 4 also confirms prevalence in the female group. Considering age incidence and gender prevalence associated with increasing life expectancy, women tend to be affected by any type of fractures, without correct diagnosis and treatment. About $40 \%$ of women aged 50 years are expected to have at least one fracture, and $20 \%$ of them are expected to suffer from multiple fractures (wrist, vertebrae, and hip are the most common). ${ }^{20}$

Since the female group is the most affected by osteoporosis, as confirmed in this study (Tables 2, 3 , and 4), the possible association between osteopenia and osteoporosis and presence of SLC was analyzed in this group (Table 5) and confirmed by the results. Only one case of SLC was found in a normal patient, which is in agreement with a previous study. ${ }^{14}$ Several theories about SLC etiology have been reported, suggesting degeneration of the ligament with deposition of the calcium salts in the fibrous tissue, or malformation due to direct ossification of the cartilaginous cells remaining in the ligament of adult patients. ${ }^{8}$ Rizzatti-Barbosa 
et al. ${ }^{23}$ used PAN while studying its prevalence in both genders and emphasized endocrine disorders in women at menopause as a possible cause for SLC. These authors concluded that this alteration is more frequent in older adults. Öztaş and Orhan ${ }^{8}$ used PAN and also observed increased SLC in older adults in a study on SLC frequency. A relationship between osteopenia and osteoporosis diagnoses and presence of SLC in the present study was found in older women, since osteoporosis was prevalent in this group (Tables 2, 3, and 4), in agreement with the findings of Rizzatti-Barbosa et al. ${ }^{23}$ and Öztaş and Orhan. ${ }^{8}$ Okabe et al. ${ }^{24}$ reported a significant association between length of the stylohyoid process and serum calcium concentration. Since calcium intake is the treatment of choice for osteoporotic patients, results from this study are in agreement with those reported by Okabe et al. ${ }^{24}$ Therefore, deposition of calcium salts in the fibrous tissue is the most likely cause of SLC.

The most useful techniques for SLC evaluation include PAN, lateral cephalogram, postero-anterior skull view, lateral oblique mandible view, and Towne's view, computed tomography, and magnetic resonance imaging. ${ }^{8}$ However, Okabe et al. ${ }^{24}$ stated that PAN might be of no value in the diagnosis of Eagle's syndrome. When in presence of a nodular mass on the SLC extension, dentists should use computed tomography to clearly distinguish between them. The CBCT technique provides accurate and reliable linear measurements, 3D information, and multiplanar views from dental and maxillofacial structures..$^{9-12}$ Size and morphology of SLC can be easily assessed. ${ }^{12}$

In conclusion, the present study suggests that (1) panoramic radiography and computed tomography images are accurate enough for osteopenia and osteoporosis diagnoses, with a low disagreement rate between methods, and (2) there is a significant correlation between presence of stylohyoid ligament calcification and osteopenia and osteoporosis diagnoses in older women.

\section{REFERENCES}

1. North American Menopause Society. The role of calcium in peri- and postmenopausal women: 2006 position statement of the North American Menopause Society. Menopause. 2006 Nov-Dec;13(6):862-77; quiz 878-80.

2. Dervis E. Oral implications of osteoporosis. Oral Surg Oral Med Oral Pathol Oral Radiol Endod. 2005 Sep;10o(3):349-56.

3. Vlasiadis KZ, Damilakis J, Velegrakis GA, Skouteris CA, Fragouli I, Goumenou A, et al. Relationship between BMD, dental panoramic radiographic findings and biochemical markers of bone turnover in diagnosis of osteoporosis. Maturitas. 2008 Mar 20;59(3):226-33.

4. Klemetti E, Kolmakov S, Heiskanen P, Vainio P, Lassila V. Panoramic mandibular index and bone mineral densities in postmenopausal women. Oral Surg Oral Med Oral Pathol. 1993 Jun;75(6):774-9.

5. Devlin H. Identification of the risk for osteoporosis in dental patients. Dent Clin North Am. 2012 Oct;56(4):847-61.

6. Garay I, Netto HD, Olate S. Soft tissue calcified in mandibular angle area observed by means of panoramic radiography. Int J Clin Exp Med. 2014 Jan 15;7(1):51-6. eCollection 2014.

7. White SC, Pharoah MJ. Oral Radiology: Principles and In-

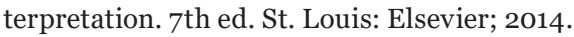

8. Öztaş B, Orhan K. Investigation of the incidence of stylohyoid ligament calcifications with panoramic radiographs. J Investig Clin Dent. 2012 Feb;3(1):30-5.

9. Scarfe WC, Li Z, Aboelmaaty W, Scott SA, Farman AG. Maxillofacial cone beam computed tomography: essence, elements and steps to interpretation. Aust Dent J. 2012 Mar;57 Suppl 1:46-6o.

10. American Dental Association Council on Scientific Affairs. The use of cone-beam computed tomography in dentistry: an advisory statement from the American Dental Association Council on Scientific Affairs. J Am Dent Assoc. 2012 Aug;143(8):899-902.

11. Koh KJ, Kim KA. Utility of the computed tomography indices on cone beam computed tomography images in the diagnosis of osteoporosis in women. Imaging Sci Dent. 2011 Sep;41(3):101-6.

12. Ilgüy D, Ilgüy M, Fişekçioğlu E, Dölekoğlu S. Assessment of the stylohyoid complex with cone beam computed tomography. Iran J Radiol. 2012 Dec;10(1):21-6.

13. Klemetti E, Kolmakov S, Kröger H. Pantomography in assessment of the osteoporosis risk group. Scand J Dent Res. 1994 Feb;102(1):68-72. 
14. Watanabe PC, Dias FC, Issa JP, Monteiro SA, de Paula FJ, Tiossi R. Elongated styloid process and atheroma in panoramic radiography and its relationship with systemic osteoporosis and osteopenia. Osteoporos Int. 2010 May;21(5):831-6.

15. Agresti A. Categorical Data Analysis. 2nd ed. New York: John Wiley and Sons; 2002.

16. Neter J, Kutner MH, Nachtsheim CJ, Wasserman W. Applied linear statistical models. 4 th ed. USA: Times Mirror Higher Education Group; 1996.

17. Institute of Medicine, Food and Nutrition Board, Committee to Review Dietary Reference Intakes for Vitamin D and Calcium. Dietary Reference Intakes for Calcium and Vitamin D. Washington, DC: The National Academy Press; 2010.

18. Nordin BE. Calcium and osteoporosis. Nutrition. 1997 JulAug;13(7-8):664-86.

19. Tuck SP, Datta HK. Osteoporosis in the aging male: treatment options. Clin Interv Aging. 2007;2(4):521-36.
20. Reginster JY, Sarlet N, Lecart MP. Fractures in osteoporosis: the challenge for the new millennium. Osteoporos Int. 2005 Jan;16 Suppl 1:S1-3.

21. Devlin H, Horner K. Mandibular radiomorphometric indices in the diagnosis of reduced skeletal bone mineral density. Osteoporos Int. 2002 May;13(5):373-8.

22. Arifin AZ, Asano A, Taguchi A, Nakamoto T, Ohtsuka M, Tsuda M, et al. Computer-aided system for measuring the mandibular cortical width on dental panoramic radiographs in identifying postmenopausal women with low bone mineral density. Osteoporos Int. 2006;17(5):753-9.

23. Rizzatti-Barbosa CM, Ribeiro MC, Silva-Concilio LR, Di Hipolito O, Ambrosano GM. Is an elongated stylohyoid process prevalent in the elderly? A radiographic study in a Brazilian population. Gerodontology. 2005 Jun;22(2):112-5.

24. Okabe S, Morimoto Y, Ansai T, Yamada K, Tanaka T, Awano $\mathrm{S}$, et al. Clinical significance and variation of the advanced calcified stylohyoid complex detected by panoramic radiographs among 80-year-old subjects. Dentomaxillofac Radiol. 2006 May;35(3):191-9. 